\title{
Thyroid Hyperactivity Induced by Methimazole, Spironolactone and Phenobarbital in Marmosets (Callithrix jacchus): Histopathology, Plasma Thyroid Hormone Levels and Hepatic $\mathbf{T}_{4}$ Metabolism
}

\author{
Yoshimasa KURATA, Yumi WAKO, Keisuke TANAKA ${ }^{1)}$, Yoshimi INOUE²) and Futoshi MAKINODAN \\ Mitsubishi Chemical Safety Institute Ltd., 14 Sunayama, Hasaki-machi, Kashima-gun, Ibaraki 314-0255, ${ }^{1)}$ Clinical Development \\ Department, Mitsubishi-Tokyo Pharmaceuticals Inc., 2-2-6 Nihonbashi-honcho, Chuo-ku, Tokyo 103-8405 and ${ }^{2)}$ Yokohama Research \\ Center, Mitsubishi-Tokyo Pharmaceuticals Inc., 1000 Kamoshida, Aoba-ku, Yokohama, Kanagawa 227-0033, Japan
}

(Received 3 December 1999/Accepted 23 February 2000)

\begin{tabular}{l} 
ABSTRACT. To determine drug-induced hyperfunction of marmoset thyroids due to inhibition of synthesis or enhancement of metabolic \\
elimination of thyroid hormones, males were orally administered 10 and $30 \mathrm{mg} / \mathrm{kg} / \mathrm{day}$ methimazole $(\mathrm{MMI}), 30$ and $100 \mathrm{mg} / \mathrm{kg} / \mathrm{day}$ \\
spironolactone (SPL), or $50 \mathrm{mg} / \mathrm{kg} / \mathrm{day}$ phenobarbital $(\mathrm{PB})$ for 4 weeks. MMI caused marked hypertrophy of follicular epithelial cells in \\
accordance with a significant decrease in the plasma thyroxin $\left(\mathrm{T}_{4}\right)$ level. Hypertrophied epithelial cells were filled with dilated rough \\
endoplasmic reticulum and reabsorbed intracellular colloids, and the luminal surface was covered with abundant microvilli. The colloid \\
included vacuoles positive to anti $\mathrm{T}_{4}$ immuno-staining. SPL and PB also caused similar histomorphological changes, although they were \\
less severe than those due to MMI and were not clearly associated with decrease in the plasma $\mathrm{T}_{4}$ levels. Hepatic $\mathrm{T}_{4} \mathrm{UDPGT}$ activities \\
tended to increase due to SPL and PB treatment, however, which were not so significant as increases in microsomal cytochrome P-450 \\
contents. Some animals treated with SPL and PB showed marked increases in thyroid weights due to inactive dilated follicles. In \\
conclusion, hyperactivity of thyroid follicles was induced in marmosets not only due to inhibition of $\mathrm{T}_{4}$ synthesis produced by MMI but \\
also because of enhancement of hepatic $\mathrm{T}_{4}$ elimination produced by SPL and PB. However, hypertrophic effects of SPL and PB were less \\
severe than MMI, because plasma $\mathrm{T}_{4}$ levels were maintained at almost pretreatment or control levels after SPL or PB treatment.-KEY \\
woRDS: marmoset, methimazole, phenobarbital, spironolactone, thyroid hyperactivity. \\
\hline
\end{tabular}

Many chemicals cause thyroid proliferative lesions through non-genotoxic mechanisms in the rat. These chemicals disturb the hypothalamus-pituitary-thyroid gland axis by inhibiting thyroid hormone synthesis (i.e. antithyroid drugs) or by enhancing hormone metabolism (i.e. hepatic microsomal enzyme inducers) and cause thyroid proliferative lesions secondary to hormone imbalance. Under normal conditions, circulating levels of thyroid hormones are maintained at constant levels via the feedback mechanism among the hypothalamus, pituitary and thyroid glands. Continuous reduction in circulating levels of thyroid hormones due to chemical-treatment also results in a compensatory increase of thyroid stimulating hormone (TSH) through the feedback mechanism. Overstimulation of the thyroid gland by TSH induces follicular cell hypertrophy, hyperplasia and finally neoplasia $[3,6,8$, 10, 21].

However, there are marked species differences in thyroid gland physiology. The most obvious species difference between the rat and humans is the lack of thyroxin binding globulin (TBG) in the rat $[13,24]$. TBG has the highest affinity for thyroxin [4]. Lack of this protein leads to more $\mathrm{T}_{4}$ free of protein binding and makes it easier to remove from the body in rats than in humans. Therefore, the halflife of serum $\mathrm{T}_{4}$ is 12 to $24 \mathrm{hrs}$ in the rat versus 6 to 7 days in humans and serum TSH is 20-fold higher in the rat compared with humans [10]. As mentioned above, the rat is much more sensitive to the induction of thyroid gland neoplasia secondary to hormone imbalance than humans $[18,28]$.

Although it is well accepted that the species difference exists in thyroid gland neoplasia secondary to hormone imbalance, this concept has been exiguously examined in primates. In this study, we investigated the effects of three compounds on the thyroid gland, the plasma $\mathrm{T}_{3}$ and $\mathrm{T}_{4}$ levels and the hepatic microsomal enzymes in the marmoset lacking TBG similar to rats $[1,23]$. The compounds used were SPL, the aldosterone antagonist, PB, the anticonvulsant or sedative, and MMI, the antithyroid drug, all of which have hyperactive effects on pituitary-thyroid gland homeostasis in rats $[17,22,26]$.

\section{MATERIALS AND METHODS}

Animals and treatment: Male common marmosets (Callithrix jacchus) were purchased from CLEA Japan (Kanagawa, Japan) or were bred in-house. Animals were housed individually in stainless steel wire-mesh cages in a rearing room maintained at a temperature of $26 \pm 2{ }^{\circ} \mathrm{C}$, a relative humidity of $50 \pm 10 \%$, a ventilation of 15 times per hour, and a light/dark cycle of $12 \mathrm{hr}$. The mixture of the pellet diet for new-world monkeys (SPS, Oriental Yeast, Tokyo, Japan) and additives (water, honey, vitamin $\mathrm{D}_{3}$ and ascorbic acid) was given as the main diet, and boiled egg and banana were given as supplemental food. Tap water, passed through a $5 \mu \mathrm{m}$ filter and irradiated by UV, was 
Table 1. Group constitution of the study

\begin{tabular}{lll}
\hline Test substance & Dose $(\mathrm{mg} / \mathrm{kg} /$ day $)$ & Number and sex of animals \\
\hline Control & Vehicle & 6 males \\
$\mathrm{SPL}^{\text {b) }}$ & 30 and 100 & 3 males in each dose level \\
$\mathrm{PB}^{\mathrm{c})}$ & 50 & 3 males \\
$\mathrm{MMI}^{\mathrm{d})}$ & 10 and 30 & 3 males in each dose level \\
\hline
\end{tabular}

a) Test substance were suspended in $0.5 \%$ carboxymethylcellurose$\mathrm{Na}$ (Wako Pure Chemical, Osaka, Japan) solution, and the dosing volume of each group was $5 \mathrm{ml} / \mathrm{kg}$.

b) SPL was synthesized at Mitsubishi Chemical (Tokyo, Japan).

c) PB was purchased from Wako Pure Chemical (Osaka, Japan).

d) MMI was purchased from Aldrich (Milwaukee, Wi).

available ad libitum from water bottles. After approximately 2 months of acclimatization, twenty-one animals were divided into 6 groups as shown in Table 1 . The groups were treated orally once daily for 28 consecutive days. Control animals were treated with vehicle. At the commencement of the treatment, body weights ranged from 271 to $401 \mathrm{~g}$ and ages ranged from 17 to 42 months. High doses of MMI and SPL, and $50 \mathrm{mg} / \mathrm{kg}$ / day $\mathrm{PB}$, which were decided on the basis of the preliminary study, were maximum tolerated doses without death or severe body weight reduction for marmosets in repeated administrations. The animals were treated with appropriate care and respect, according to the Guidelines for Animal Experimentation of our Laboratory, Mitsubishi Chemical Safety Institute Ltd.

Liver biopsy: To obtain pretreatment values of hepatic microsomal enzyme activity, a liver biopsy was performed on all animals 5 or 6 weeks before the commencement of the drug treatment under sodium pentobarbital $(30 \mathrm{mg} / \mathrm{kg}$, ip) anesthesia. After disinfecting the skin with povidoneiodine and $70 \%$ ethanol, an abdominal wall incision was made over the mid-line, and the wedge of the right lateral lobe was excised. A collagen sheet (AVITEN, Zeria Shinyaku, Tokyo, Japan) was used for hemostasis of the excised site in the liver. The suture site was disinfected with povidone-iodine and antibiotics.

Analysis of plasma triiodo thyronine $\left(T_{3}\right)$ and thyroxin $\left(T_{4}\right)$ : Prior to, and two and four weeks after commencement of treatment, blood samples were obtained from the femoral vein. The plasma was then separated by centrifugation. Total and free $\mathrm{T}_{3}$, and total and free $\mathrm{T}_{4}$ concentrations were determined by radioimmunoassay using commercially available kits (Amerlex $\mathrm{M} \mathrm{T}_{3}$, free $\mathrm{T}_{3}, \mathrm{~T}_{4}$, and free $\mathrm{T}_{4}$, respectively; Amersham, International plc, UK). Plasma samples were stored at $-80^{\circ} \mathrm{C}$ until analysis.

Analysis of cytochrome P-450 content: Homogenates of the liver samples obtained at biopsy and autopsy were prepared with $0.25 \mathrm{M}$ sucrose, $10 \mathrm{mM}$ HEPES, and $1 \mathrm{mM}$ dithiothreitol solution ( $\mathrm{pH}$ 7.0) using Potter-type glass and a teflon homogenizer. Then, microsomes were obtained by centrifugations $(10,000 \times \mathrm{g}$ for $20 \mathrm{~min}$ and $100,000 \times \mathrm{g}$ for $60 \mathrm{~min}$ at $4^{\circ} \mathrm{C}$ ) and suspended in phosphate buffer ( $\left.\mathrm{pH} 7.4\right)$ containing $3 \mathrm{mM}$ EDTA and $1 \mathrm{mM}$ dithiothreitol.
Cytochrome P450 contents in hepatic microsomes were determined from the reduced carbon monoxide difference spectrum using a spectrophotometer based on the extinction coefficient of $91 \mathrm{mM}^{-1} \mathrm{~cm}^{-1}$ [20]. The protein concentration was determined using the method of Lowry et al. [14] using bovine serum albumin as a standard. Microsome samples were stored at $-80^{\circ} \mathrm{C}$ until assayed.

Analysis of thyroxin UDP-glucuronosyltransferase $\left(T_{4}\right.$ $U D P G T): \mathrm{T}_{4}$ UDPGT activities in hepatic microsomes were determined according to the method of Beetstra et al. [2]. The microsome sample $(1 \mathrm{mg}$ protein $/ \mathrm{ml})$ was incubated with $1 \mu \mathrm{M} \mathrm{T}_{4}$ (Sigma, St. Louis, MO, U.S.A.) and $0.1 \mu \mathrm{Ci}$ ${ }^{125} \mathrm{I}_{-} \mathrm{T}_{4}$ (New England Nuclear, Boston, MA, U.S.A.) in 0.1 $\mathrm{M}$ Tris- $\mathrm{HCl}$ buffer ( $\mathrm{pH} \mathrm{7.4)} \mathrm{containing} 5 \mathrm{mM} \mathrm{MgCl}_{2}$ and $0.05 \%$ Brij 56 (Sigma, St. Louis, MO, U.S.A.). The reaction was initiated by adding UDP glucuronic acid (Nacalai Tesque, Kyoto, Japan) at a final concentration of 5 $\mathrm{mM}$. It was reacted for $120 \mathrm{~min}$ at $37^{\circ} \mathrm{C}$, and was terminated by adding ice-cold methanol. After centrifugation $(10,000 \times \mathrm{g}$ for $2 \mathrm{~min})$, the supernatant was filtered through a $0.45 \mu \mathrm{m}$ LCR membrane tube (Ultrafree C3-LH, Millipore, Tokyo, Japan), and was used for HPLC analysis [7]. An Inertsil ODS-2 column $(4.6 \times 150 \mathrm{~mm}$; GL Science, Tokyo, Japan) and 57:43 (v/v) methanol/20 mM potassium phosphate buffer containing $1 \%(\mathrm{v} / \mathrm{v})$ triethylamine adjusted to $\mathrm{pH} 7.0$ with orthophosphoric acid was used for separation (flow rate: $1.0 \mathrm{~m} / / \mathrm{min}$ ). The peaks were detected using a radioisotope detector and the activity was calculated using the $\%$ of radioactivity of formed $\mathrm{T}_{4^{-}}$ glucuronide.

Pathological examination: On the day after the final dosage, all animals were sacrificed by exsanguination of the abdominal aorta under sodium pentobarbital anesthesia and underwent necropsy. The liver and thyroid were fixed in $10 \%$ neutral buffered formalin. Light microscopic examination was performed on the sections of both organs routinely stained with hematoxylin and eosin. Additionally, $\mathrm{T}_{4}$ immuno-staining using polyclonal antibody (rabbit antihuman thyroxin, DAKO Japan, Kyoto, Japan) and PCNA immuno-staining using monoclonal anti-PCNA antibody (PC10, DAKO Japan, Kyoto, Japan) were performed on the thyroid sections. Portions of the thyroid and liver were fixed in $0.1 \mathrm{M}$ phosphate-buffered $3 \%$ glutaraldehyde solution and then in $0.1 \mathrm{M}$ phosphate-buffered $1 \%$ osmium tetroxide. Electron microscopic examination was performed on the thin sections stained with uranyl acetate and lead citrate.

Statistical analysis: Data are expressed as mean \pm standard deviation. Statistical analyses were performed using paired $t$ test and/or Student's $t$-test. The significance level was set at $\mathrm{P}<0.05$ and 0.01 .

\section{RESULTS}

Body weight change, Liver and Thyroid weights: Table 2 shows the body, liver and thyroid weights. The final body weights were not affected by any treatment. PB caused 
Table 2. Final body weight, and liver and thyroids weights in marmosets treated with SPL, PB and MMI

\begin{tabular}{|c|c|c|c|c|c|c|c|c|}
\hline \multirow{2}{*}{\multicolumn{3}{|c|}{$\begin{array}{l}\text { Test Dose } n \\
\text { substance }(\mathrm{mg} / \mathrm{kg} / \text { day })\end{array}$}} & \multirow{2}{*}{\multicolumn{2}{|c|}{$\begin{array}{c}\text { Final body weight } \\
\mathrm{g}(\% \text { to initial value })\end{array}$}} & \multirow{2}{*}{\multicolumn{2}{|c|}{$\begin{array}{c}\text { Liver weight } \\
\mathrm{g}(\% \text { to } \mathrm{FBW})\end{array}$}} & \multirow{2}{*}{\multicolumn{2}{|c|}{$\begin{array}{c}\text { Thyroid weight } \\
\mathrm{mg}\left(\times 10^{-3} \% \text { to } \mathrm{FBW}\right)\end{array}$}} \\
\hline & & & & & & & & \\
\hline Control & - & 6 & $322 \pm 33$ & $(101 \pm 4)$ & $11.3 \pm 1.1$ & $(3.53 \pm 0.31)$ & $59.8 \pm 6.0$ & $(18.9 \pm 3.7)$ \\
\hline \multirow[t]{2}{*}{ SPL } & 30 & 3 & $308 \pm 45$ & $(97 \pm 4)$ & $13.1 \pm 4.0$ & $(4.21 \pm 0.78)$ & $68.8 \pm 6.2$ & $(22.6 \pm 0.4)$ \\
\hline & 100 & 3 & $315 \pm 37$ & $(97 \pm 2)$ & $12.6 \pm 1.0$ & $(4.01 \pm 0.24)^{*}$ & $87.0 \pm 23.6$ & $(27.6 \pm 7.0)$ \\
\hline PB & 50 & 3 & $325 \pm 37$ & $(102 \pm 1)$ & $18.1 \pm 1.8^{* *}$ & $(5.57 \pm 0.08)^{* *}$ & $91.9 \pm 37.1$ & $(29.3 \pm 15.2)$ \\
\hline \multirow[t]{2}{*}{ MMI } & 10 & 3 & $315 \pm 26$ & $(103 \pm 1)$ & $12.3 \pm 1.1$ & $(3.91 \pm 0.05)^{*}$ & $53.3 \pm 10.5$ & $(17.0 \pm 3.5)$ \\
\hline & 30 & 3 & $323 \pm 20$ & $(104 \pm 2)$ & $13.3 \pm 2.1$ & $(4.11 \pm 0.43)$ & $65.6 \pm 13.0$ & $(20.6 \pm 5.3)$ \\
\hline
\end{tabular}

Marmosets were treated orally for 28 consecutive days. Data are shown in mean \pm S.D. for 3 or 6 animals per group.

$* \mathrm{P}<0.05, * * \mathrm{P}<0.001$ against control (Student's $t$-test).
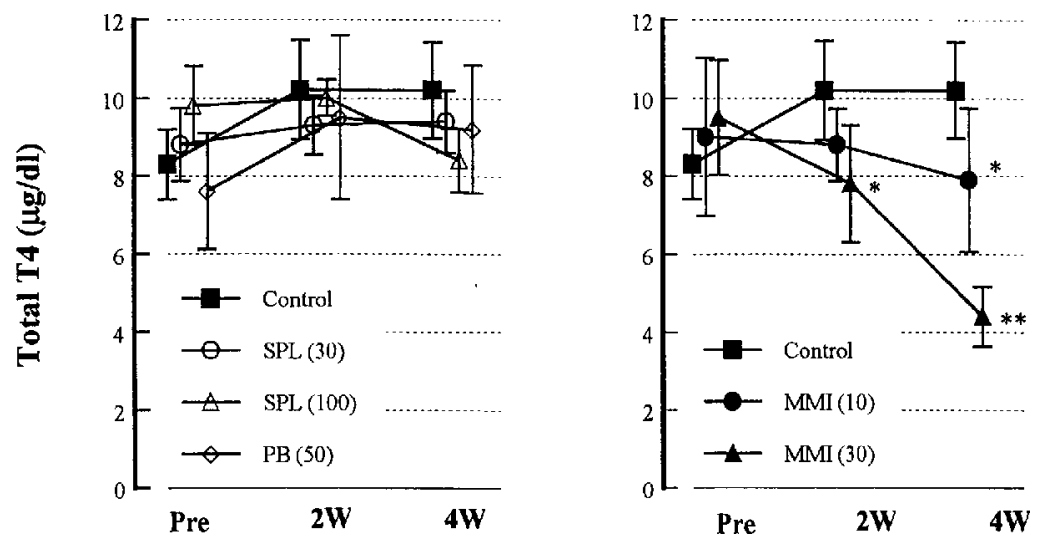

Fig. 1. Plasma total $\mathrm{T}_{4}$ concentration in the marmosets treated orally with saline (control, ), Spironolactone (SPL) $30(\bigcirc)$ and $100(\triangle) \mathrm{mg} / \mathrm{kg} /$ day, Phenobarbital $(\mathrm{PB}) 50(\diamond) \mathrm{mg} /$ $\mathrm{kg} /$ day and Methimazole (MMI) $10(\boldsymbol{O})$ and $30(\boldsymbol{\Delta}) \mathrm{mg} / \mathrm{kg} /$ day for 28 consecutive days.

significant increases of the absolute and the relative (against body weight) liver weights. The thyroid weights were markedly increased at $100 \mathrm{mg} / \mathrm{kg} / \mathrm{day}$ SPL and $50 \mathrm{mg} /$ $\mathrm{kg} /$ day PB due to the dilated and colloid-rich follicles observed in one animal in each group, although the changes were not statistically significant due to the large variation. MMI did not affect the thyroid weight at any dose, although the substance caused significant hypertrophy of follicular cells.

Plasma $T_{3}$ and $T_{4}$ concentration: Figures 1 and 2 show plasma total and free $T_{4}$ levels. Plasma $T_{4}$ level in marmosets receiving $100 \mathrm{mg} / \mathrm{kg} /$ day SPL showed only a slight reduction compared with their pretreatment and control value after 4 weeks of treatment. PB did not affect the plasma total and free $\mathrm{T}_{4}$ levels. However, MMI markedly decreased plasma total and free $\mathrm{T}_{4}$ levels at all doses in a dose-dependent manner. Treatment related changes in plasma total and free $T_{3}$ concentrations were not obvious in any treatment group due to large variations.

Hepatic cytochrome P450 content: Table 3 shows hepatic microsomal cytochrome P450 contents. Cytochrome P450 contents in SPL-treated marmosets tended to be increased or were significantly increased at all doses compared with their individual pretreatment values and with control value on a milligram microsomal protein, a gram liver and a total liver basis. In marmosets treated with $\mathrm{PB}$, about 5 or 10fold increases in cytochrome P450 contents were observed on a microsomal protein and a gram liver basis, respectively, compared with their pretreatment value and the content was about 14 times higher than the control value on a total liver basis. However, cytochrome P450 contents in MMI-treated marmosets tended to decrease at all doses.

Hepatic $T_{4}$ UDPGT activity: Table 4 shows the hepatic $\mathrm{T}_{4}$ UDPGT activities. $\mathrm{T}_{4}$ UDPGT activity tended to be increased on a gram liver or a total liver basis by the treatment with SPL at all doses and PB compared with their pretreatment or control values. However, the changes were not statistically significant except in $100 \mathrm{mg} / \mathrm{kg} /$ day SPL, and were less obvious as compared with increases in cytochrome P450 contents. No change in $\mathrm{T}_{4}$ UDPGT activity was observed in marmosets treated with MMI.

Histopathological findings: Histopathological findings of the thyroids and liver were summarized in Table 5. In the thyroids, 30 and $100 \mathrm{mg} / \mathrm{kg} /$ day SPL, $50 \mathrm{mg} / \mathrm{kg} / \mathrm{day} \mathrm{PB}$ 

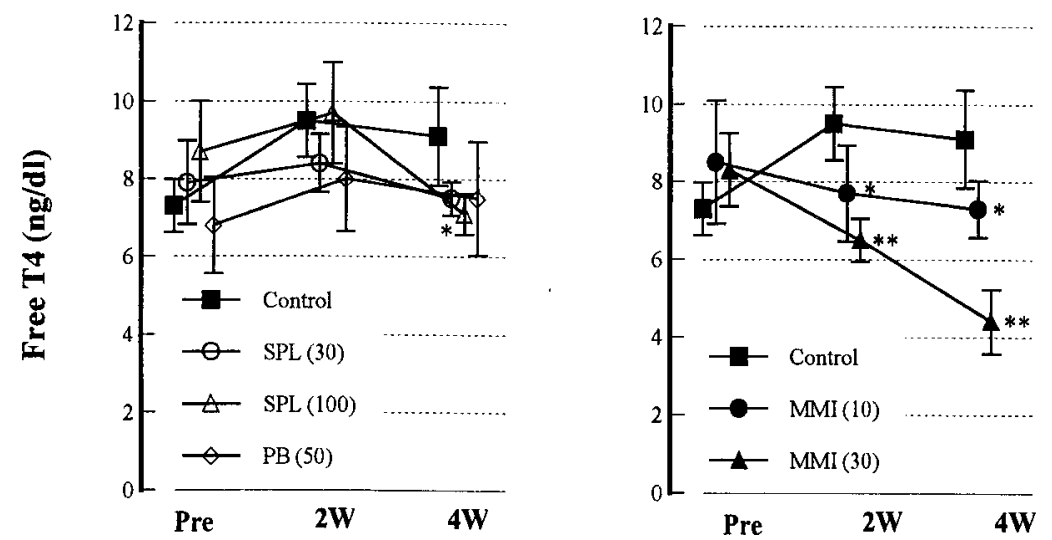

Fig. 2. Plasma free $\mathrm{T}_{4}$ concentration in the marmosets treated orally with saline (control,

- Spironolactone (SPL) $30(\bigcirc)$ and $100(\triangle) \mathrm{mg} / \mathrm{kg} /$ day, Phenobarbital (PB) 50 $(\diamond) \mathrm{mg} / \mathrm{kg} / \mathrm{day}$ and Methimazole (MMI) $10(\boldsymbol{O})$ and $30(\boldsymbol{\Delta}) \mathrm{mg} / \mathrm{kg} / \mathrm{day}$ for 28 consecutive days.

Table 3. Hepatic P-450 contents in marmosets treated with SPL, PB and MMI

\begin{tabular}{|c|c|c|c|c|c|c|c|}
\hline \multirow{2}{*}{\multicolumn{2}{|c|}{$\begin{array}{l}\text { Test } \quad \text { Dose } \\
\text { substances }(\mathrm{mg} / \mathrm{kg} / \text { day })\end{array}$}} & \multirow[t]{2}{*}{$\mathrm{n}$} & \multicolumn{2}{|c|}{$\mathrm{nmol} / \mathrm{mg}$ protein } & \multicolumn{2}{|c|}{$\mathrm{nmol} / \mathrm{g}$ liver } & \multirow{2}{*}{$\frac{\mathrm{nmol} / \mathrm{liver}}{28 \text { days after }}$} \\
\hline & & & Pretreatment & 28 days after & Pretreatment & 28 days after & \\
\hline Control & - & 6 & $0.38 \pm 0.11$ & $0.39 \pm 0.11$ & $11.6 \pm 5.5$ & $11.1 \pm 3.2$ & $110 \pm 64$ \\
\hline \multirow[t]{2}{*}{ SPL } & 30 & 3 & $0.47 \pm 0.05$ & $0.80 \pm 0.07 * * \#$ & $12.0 \pm 2.7$ & $29.5 \pm 0.9 * *$ \# & $388 \pm 126^{* *}$ \\
\hline & 100 & 3 & $0.41 \pm 0.13$ & $0.65 \pm 0.14^{* \#}$ & $11.5 \pm 3.9$ & $22.7 \pm 4.6^{* * \# \#}$ & $288 \pm 74 * *$ \\
\hline PB & 50 & 3 & $0.47 \pm 0.11$ & $2.22 \pm 0.18^{* * \# \#}$ & $9.4 \pm 2.9$ & $85.8 \pm 40.6^{* *}$ & $1505 \pm 582^{* *}$ \\
\hline \multirow[t]{2}{*}{ MMI } & 10 & 3 & $0.48 \pm 0.05$ & $0.46 \pm 0.07$ & $13.2 \pm 1.3$ & $10.8 \pm 1.0^{\#}$ & $134 \pm 21$ \\
\hline & 30 & 3 & $0.51 \pm 0.12$ & $0.30 \pm 0.11^{\# \#}$ & $11.9 \pm 3.0$ & $8.2 \pm 2.2$ & $113 \pm 43$ \\
\hline
\end{tabular}

Marmosets were treated orally for 28 consecutive days. Data are shown in mean \pm S.D. for 3 or 6 animals per group. $* \mathrm{P}<0.05,{ }^{*} * \mathrm{P}<0.01$ against control (Student's I-test).

${ }^{\#} \mathrm{P}<0.05,{ }^{\# \#} \mathrm{P}<0.01$ against pretreatment value (paired $t$-test).

Table 4. Hepatic $\mathrm{T}_{4}$ UDPGT activities in marmosets treated with SPL, PB and MMI

\begin{tabular}{lcccccccc}
\hline \multirow{2}{*}{$\begin{array}{l}\text { Test } \\
\text { substances }\end{array}$} & $\begin{array}{c}\text { Dose } \\
(\mathrm{mg} / \mathrm{kg} / \mathrm{day})\end{array}$ & $\mathrm{n}$ & \multicolumn{2}{c}{$\mathrm{pmol} / \mathrm{mg}$ protein/min. } & & \multicolumn{2}{c}{ pmol/g liver/min. } & pmol/liver/min. \\
Control & - & 6 & $0.64 \pm 0.14$ & $0.59 \pm 0.07$ & & $19.1 \pm 4.7$ & $17.0 \pm 3.4$ & $192 \pm 38$ \\
\hline SPL & 30 & 3 & $0.55 \pm 0.21$ & $0.59 \pm 0.12$ & & $14.4 \pm 6.5$ & $21.6 \pm 3.1$ & $290 \pm 127$ \\
& 100 & 3 & $0.69 \pm 0.10$ & $0.71 \pm 0.08$ & & $19.6 \pm 2.0$ & $24.8 \pm 2.2^{*}$ & $311 \pm 8^{*}$ \\
\hline PB & 50 & 3 & $0.96 \pm 0.17$ & $0.75 \pm 0.13^{*}$ & & $18.7 \pm 2.0$ & $27.7 \pm 8.9^{*}$ & $492 \pm 133^{* *}$ \\
\hline MMI & 10 & 3 & $0.66 \pm 0.04$ & $0.75 \pm 0.14^{*}$ & & $18.4 \pm 3.0$ & $21.1 \pm 5.2$ & $261 \pm 78$ \\
& 30 & 3 & $0.72 \pm 0.11$ & $0.50 \pm 0.03$ & & $16.7 \pm 0.5$ & $14.3 \pm 2.9$ & $188 \pm 36$ \\
\hline
\end{tabular}

Marmosets were treated orally for 28 consecutive days. Data are shown in mean \pm S.D. for 3 or 6 animals per group.

$* \mathrm{P}<0.05$ against control (Student's $t$-test).

and $10 \mathrm{mg} / \mathrm{kg} /$ day MMI induced mild hypertrophy of follicular cells, and the most prominent hypertrophy was induced by $30 \mathrm{mg} / \mathrm{kg} /$ day MMI. The follicles were lined by cuboidal to columnar epithelial cells and contained faint eosinophilic and scanty colloid (Fig. 3). Colloid vacuoles called reabsorption lacunae, which showed positive staining for anti-T4 antibody, appeared in all treatments (Fig. 4). However, treatment-related change was not observed in the PCNA-index in any treatment groups. Dilated follicles were also present in one animal treated with $100 \mathrm{mg} / \mathrm{kg} /$ day SPL and $50 \mathrm{mg} / \mathrm{kg} /$ day PB in each group. These follicles were lined with flattened epithelial cells, and the thyroids 
Table 5. Pathological findings of the liver and thyroids in marmosets treated with SPL, $\mathrm{PB}$ and $\mathrm{MMI}$

\begin{tabular}{|c|c|c|c|c|c|c|}
\hline \multirow{2}{*}{$\begin{array}{l}\text { Organs } \\
\text { Findings }\end{array}$} & \multirow{2}{*}{$\begin{array}{l}\text { Test substances: } \\
\text { ose ( } \mathrm{mg} / \mathrm{kg} / \text { day }) \text { : }\end{array}$} & \multicolumn{2}{|c|}{ SPL } & \multirow{2}{*}{$\frac{\mathrm{PB}}{50}$} & \multicolumn{2}{|c|}{ MMI } \\
\hline & & 30 & 100 & & 10 & 30 \\
\hline \multicolumn{7}{|l|}{ Thyroids } \\
\hline \multirow{2}{*}{$\begin{array}{l}\text { Hypertrophy of follicular epithelium } \\
\text { with vacuoles in the follicle }\end{array}$} & $1++^{a)}$ & 3 & 2 & 2 & - & - \\
\hline & $2+$ & - & - & - & - & 3 \\
\hline \multicolumn{2}{|l|}{ Dilatation of follicles } & - & 1 & 1 & - & - \\
\hline \multicolumn{7}{|l|}{ Liver } \\
\hline \multicolumn{2}{|c|}{ Centrilobular hypertrophy of hepatocytes } & - & - & 3 & - & - \\
\hline
\end{tabular}

Marmosets were treated orally for 28 consecutive days.

Data are shown in the number of animals with lesions for 3 animals per group. a) 1+: slight; 2+: moderate.

containing dilated follicles showed a marked increase in weight.

Ultrastructurally, the following findings were obtained from animals in all treatment groups except animals showing dilated follicles and flattened epithelial cells in SPL (100 mg/kg/day) and PB-treatment groups. Hypertrophied epithelial cells were filled with microvesicularly or cisternally dilated rough endoplasmic reticulum, which were occasionally intermingled with reabsorbed intracellular colloids. The luminal surface was covered with abundant microvilli. Ultrastructural changes caused by MMI was also most severe in three drugs (Fig. 5).

In the liver, centrilobular hepatocellular hypertrophy was observed in all animals treated with PB. Hepatocytes from the central area to midzone were swollen with eosinophilia. Hypertrophy of hepatocytes was attributed to the proliferation of the smooth endoplasmic reticulum observed using electron microscopy.

\section{DISCUSSION}

Marmosets (Callithrix jacchus) belong to the suborder Platyrrhini and inhabit the Amazon basin. This animal came to be used in toxicological studies because of ease of handling, their small size and good reproductive ability [12]. There are very few basic toxicological profiles for marmosets, thus it is important to investigate its basic toxicological profile. There are marked species differences in thyroid physiology between rats and humans, therefore, toxicological data on the thyroid obtained from primate studies might be important. However, great care must be taken when interpreting the toxicological effects on marmoset thyroid, because marmosets, like rats, lack TBG, a main carrier protein of thyroxin.

MMI, an anti-thyroid drug, impairs the synthesis of thyroid hormones by inhibiting the peroxidase [25]. In rats, a 4-fold increase in thyroid weight has been induced after one-month of MMI treatment (90 ppm in diet, approx. 9 $\mathrm{mg} / \mathrm{kg} /$ day) accompanied with diffuse hypertrophy and hyperplasia of follicular epithelial cells [26].

In the present study, MMI (10 and $30 \mathrm{mg} / \mathrm{kg} / \mathrm{day})$ induced marked hypertrophy of follicular epithelial cells in marmosets also. The appearance of reabsorption lacunae in colloids stained with anti- $\mathrm{T}_{4}$ antibody and ultrastructural findings, such as dilated rough endoplasmic reticulum, increase of reabsorbed colloid and luminal surface covered with abundant microvilli, evidenced that the follicles were activated.

Hypertrophic change was well correlated with the reduction in plasma $T_{4}$ levels. Since hepatic microsomal P450 content or $T_{4}$ UDPGT activity was not affected by MMI treatment, hyperactivities of thyroid follicles might be caused secondarily by the lowered circulating thyroid hormones due to inhibition of hormone-synthesis. However, increase in thyroid weight or hyperplastic change of follicular epithelial cells observed in rats was not seen in marmosets even at the maximum tolerated dose. This may indicate that the feedback mechanism of the hypothalamuspituitary-thyroids axis in marmosets was less sensitive to alterations in the blood $\mathrm{T}_{4}$ level than that in rats. However, it is possible that hyperplastic changes will be induced under chronic reduction of the blood $\mathrm{T}_{4}$ level, because PCB, a potent inducer on thyroid function and morphology, induced hyperplasia of follicular epithelial cells in accordance with the decrease in serum $\mathrm{T}_{4}$ and the increase in serum TSH in marmosets as well as in rats [27].

SPL, an aldosterone antagonist, is a hepatic microsomal enzyme inducer. In rats, a 13-week administration of 200 $\mathrm{mg} / \mathrm{kg} /$ day SPL caused hypertrophy of follicular cells secondary to the enhancement of $\mathrm{T}_{4}$ elimination in the liver [22]. PB was also a potent hepatic microsomal enzyme inducer in humans as well as in rats $[5,9]$. In rats, PB increased the thyroid weight with induction of hypertrophy or hyperplasia of follicular cells $[11,16]$, where the mechanism is also secondary to the enhancement of hepatic $\mathrm{T}_{4}$ elimination [17]. However, in rhesus monkeys, no changes were observed in the thyroid gland after administration of $250 \mathrm{mg} / \mathrm{kg} /$ day SPL for 52 weeks [15]. Moreover, in humans, no decrease in circulating thyroid hormone levels has been observed under conditions where hepatic microsomal enzymes are induced [19], and hypertrophic or hyperplastic change in the thyroid caused by SPL and PB has not been reported in humans. 

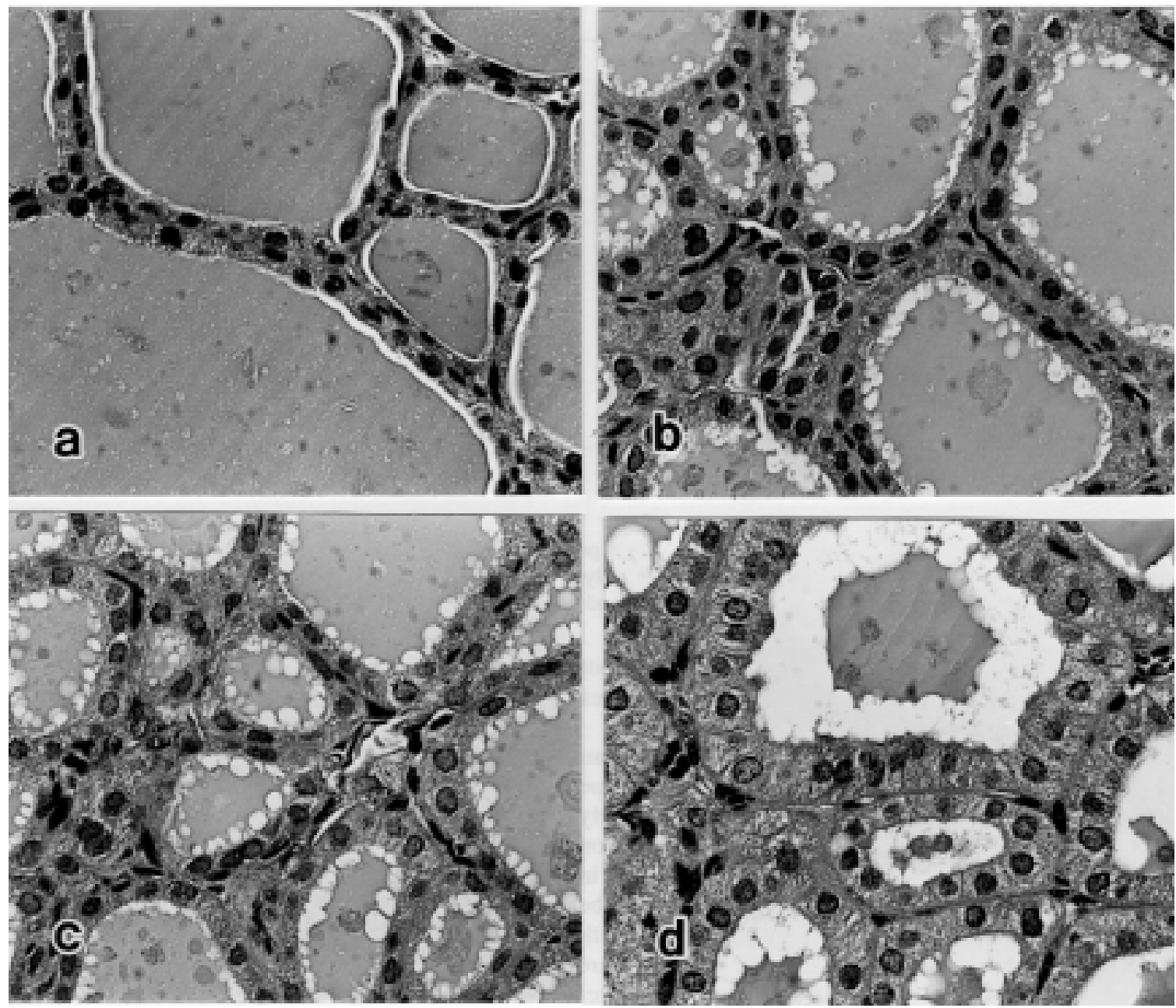

Fig. 3. Photomicrographs of hematoxylin-eosin stained sections of thyroid gland in control (a), treated with $100 \mathrm{mg} / \mathrm{kg} / \mathrm{day}$ SPL (b), $50 \mathrm{mg} / \mathrm{kg} / \mathrm{day}$ PB (c) and $30 \mathrm{mg} / \mathrm{kg} / \mathrm{day}$ MMI (d). Follicular epithelia in treated animals were taller than in control animals and absorption lacunae were prominent. $(\times 480)$
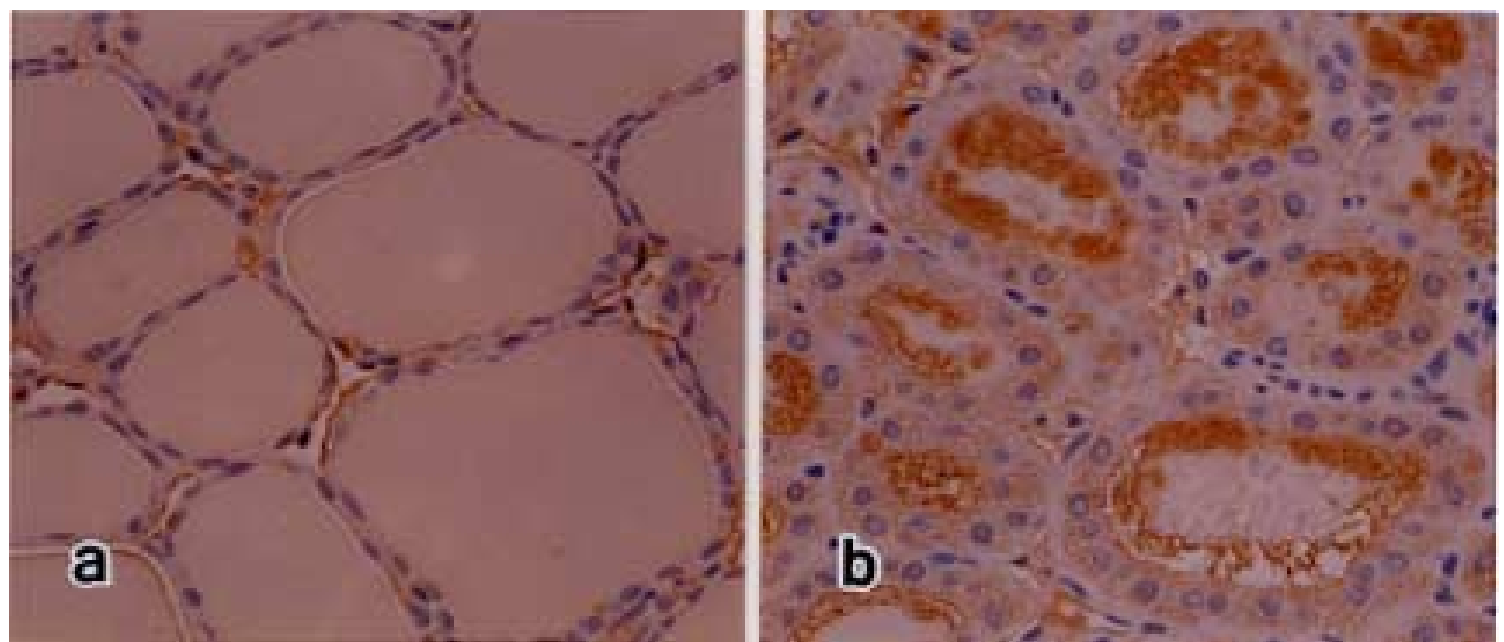

Fig. 4. Photomicrographs of $\mathrm{T}_{4}$-immunostained sections of thyroid gland in control (a) and treated with $30 \mathrm{mg} / \mathrm{kg} / \mathrm{day} \mathrm{MMI}$ (b). Colloid vacuoles showed positive staining for anti- $\mathrm{T}_{4}$ antibody in MMI-treated animals. $(\times 400)$ 

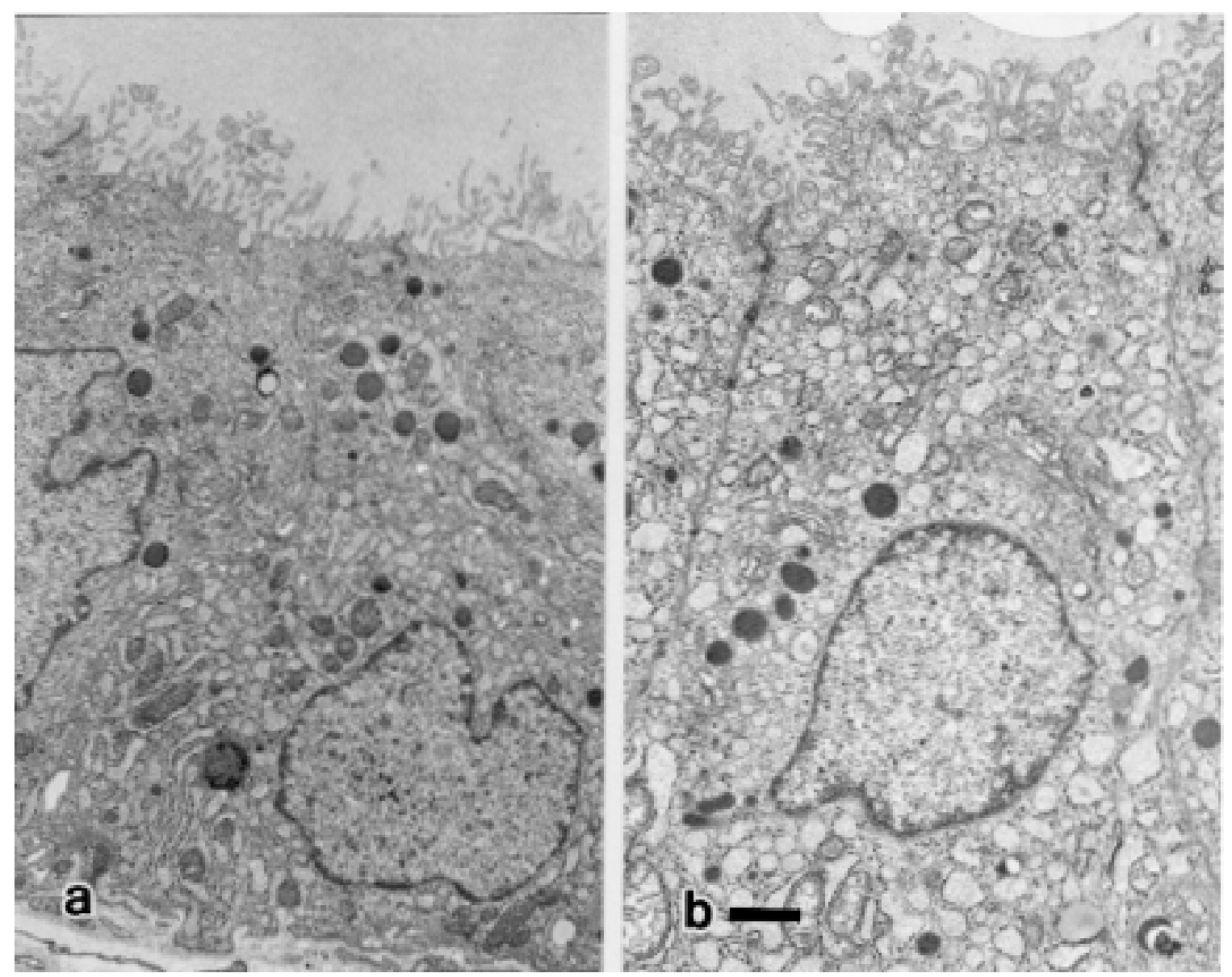

Fig. 5. Hypertrophied follicular cells in rats treated with $100 \mathrm{mg} / \mathrm{kg} / \mathrm{day}$ SPL (a) and $30 \mathrm{mg} / \mathrm{kg} / \mathrm{day}$ MMI (b). Cytoplasmic expansion is characterized by dilated profiles of rough endoplasmic reticulum and increase in number of long microvilli. Bar $=1 \mu \mathrm{m}$.

The present study demonstrated SPL and PB, as well as MMI, also induced hypertrophy of follicular cells in marmosets, and in addition, other histologic and electron microscopic changes in the thyroids were similar to that of MMI-treated marmosets. SPL and PB treatment caused a significant increase in hepatic microsomal cytochrome P450 content, and $\mathrm{T}_{4}$ UDPGT activity was also slightly increased in a dose-dependent manner. Therefore, hyperactive changes of follicular cells induced by SPL and PB in marmosets are probably secondary to hormone imbalance due to the enhancement of metabolic clearance of $\mathrm{T}_{4}$ in the liver. Seo et al. [23] reported that marmosets were lacking TBG and showed high concentrations of circulating free $T_{4}$. Thus, hyperactivity of thyroid follicles secondary to the enhancement of $\mathrm{T}_{4}$ metabolism may be due to the high concentration of the free form in marmosets, which is similar to rats. However, induction of hepatic $\mathrm{T}_{4}$ UDPGT was not so drastic as to cause reductions in plasma $\mathrm{T}_{4}$ levels, which were maintained at almost pretreatment or control levels after SPL or PB treatment. As a result, histologic changes in the thyroids might be less severe than that observed in MMI-treated marmosets. Moreover, the thyroids in some animals treated with high dose of SPL and PB showed marked increases in weights and dilated follicles with flattened lining epithelial cells. These findings suggest that follicles were in an inactive stage rather than active. These findings also indicate that hyperactivity of thyroid follicles, induced by SPL and PB treatment, may be temporary.

To confirm that the present follicular cell hypertrophy induced by SPL, PB, and MMI was secondary to hormone imbalance, it was necessary to determine the plasma TSH concentration. However, we were unable to measure the TSH concentration with the currently available kit for humans and rat TSH, due to the lack of cross-reactivity.

In conclusion, our findings indicate that not only MMI, thyroxin synthesis inhibitor, but also SPL and PB, hepatic microsomal enzyme inducers, induce hyperactivity of thyroid follicles in the marmoset as well as in the rat. Hypertrophic effects of SPL and PB, which were not associated with reductions of blood thyroid hormone levels, were less severe than that of MMI which was associated with significant reductions in the hormone levels. 
ACKNOWLEDGMENTS. Authors thank Dr. Minoru Tsuchitani for valuable discussions and Mr. Takeshi Kawasuso for good technical assistance.

\section{REFERENCES}

1. Ando, M., Seo, H., Murata, Y., Matsui, N. and Takanaka, O. 1986. Thyroxine biding protein in primate species; platyrrhini and prosimiae. Environ. Med. 30: 69-75.

2. Beetstra, J.B., Van Engelen, J.G.M., Karels, P., Van der Hoek, H.J., De Jong, M., Docter, R., Krenning, E.P., Hennemann, G., Brouwer, A. and Visser, T.J. 1991. Thyroxine and 3,3',5triiodothyronine are glucuronided in rat liver by different uridine diphosphate-glucuronyltransferases. Endocrinology 128: 741-746.

3. Capen, C.C. 1992. Pathophysiology of chemical injury of the thyroid gland. Toxicol. Lett. 64/65: 381-388.

4. Cavalieri, R.R. and Pitt-rivers, R.1981. The effects of drugs on the distribution and metabolism of thyroid hormones. Pharmacol. Rev. 33: 55-80.

5. Conney, A.H. 1967. Pharmacological implications of microsomal enzyme induction. Pharmacol. Rev. 19: 317-366.

6. Curran, P.G. and DeGroot, L.J. 1991. The effect of hepatic enzyme-inducing drugs on thyroid hormones and the thyroid gland. Endocrine. Rev. 19: 135-150.

7. Ducrotoy, G., Richert, L., De Sandro, V., Lurier, D. and Pacuad, E. 1991. Determination of ${ }^{125}$ I-labelled thyroxine glucuronide by reversed phase high performance liquid chromatography using on-line radiochemical detection to determine UDP Glucuronosyltransferase activity. J. Chromatogr. Biomed. Appl. 566: 415-426.

8. Fenner-Crisp, P.A. 1990. Application of the EPA proposal threshold policy for thyroid follicular cell neoplasia example assessment. Health Effects Division, U.S. Environmental Protection Agency, Washington, D.C.

9. Hildebrandt, A.G., Roots, I., Speck, M., Saalfrank, K. and Kewitz, H. 1975. Evaluation of parameters of drug metabolizing enzyme activity in man after administration of clemastine, phenobarbital or placebo. Eur. J. Clin. Pharmacol. 8: 327336.

10. Hill, R.N., Erdreich, L.S., Paynter, O.E., Roberts, P.A., Rosenthal, S.L. and Wilkinson, C.F. 1989. Thyroid follicular cell carcinogenesis. Fund. Appl. Toxicol. 12: 629-697.

11. Japundzic, M.M. 1969. The goitrogenic effect of phenobarbital-Na on the rat thyroid. Acta. Anat. 74: 88-96.

12. Kurata, Y., Sukegawa. J. and Toyooka, M. 1991. Use of the marmoset (Callithrix jacchus) in toxicological research. Mitsubishi Kasei R\&D Rev. 5: 1-10.

13. Larsson, M., Pettersson, T. and Carlstrom, A. 1985. Thyroid hormone binding in serum of 15 vertebrate species: Isolation of thyroxine-binding globulin and prealbumin analogs. Gen. Comp. Endcrinol. 58: 360-375.

14. Lowry, O.H., Rosebrough, N.J., Farr, A.L. and Randall, R. 1951. Protein measurement with the folin phenol reagent. $J$. Biol. Chem. 193: 265-275.

15. Lumb, G., Newberne, P., Rust, J.H. and Wagner, B. 1978. Effects in animals of chronic administration of spironolactone; A review. J. Environ. Pathol. Toxicol. 1: 641-660.

16. McClain, R. M., Posch, R. C., Bosakowski, T. and Armstrong, J. M. 1988. Studies on the mode of action for thyroid gland tumor promotion in rats by phenobarbital. Toxicol. Appl. Pharmacol. 94: 254-265.

17. McClain, R.M., Levin, A.A., Posch, R. and Downing, J.C. 1989. The effect of phenobarbital on the metabolism and excretion of thyroxine in rats. Toxicol. Appl. Pharmacol. 99: 216-228.

18. McClain, R.M. 1992. Thyroid gland neoplasia: non-genotoxic mechanisms. Toxicol. Lett. 64/65: 397-408.

19. Ohnhaus, E.E., Burgi, H., Burger, A. and Studer, H. 1981. The effect of antipyrine, phenobarbital and rifampicin on thyroid hormone metabolism in man. Eur. J. Invest. 11: 381-387.

20. Omura, T. and Sato, R. 1964. The carbon monoxide-binding pigment of liver microsomes. I. Evidence for its hemoprotein nature. J. Biol. Chem. 239: 2370-2378.

21. Paynter, O.E., Burin, G.J., Jaeger, R.B. and Gregorio, C.A. 1988. Goitrogens and thyroid follicular cell neoplasia: Evidence for a threshold process. Regul. Toxicol. Pharmacol. 8: 102-119.

22. Semler, D.E., Chengelis, C.P. and Radzialowski, F.M. 1989. The effects of chronic ingestion of spironolactone on serum thyrotropin and thyroid hormones in the male rat. Toxicol. Appl. Pharmacol. 98: 263-268.

23. Seo, H., Ando, M., Yamauchi, K., Matsui, N. and Takenaka, O. 1989. Plasma thyroxine-binding proteins and thyroid hormone levels in primate species; Is callithricidae thyroid hormone resistant? Endocrinol. Japon 36: 665-673.

24. Sutherland, R.L. and Brandn, M.R. 1976. The thyroxinebinding properties of rat and rabbit serum proteins. Endocrinology 98: 91-98.

25. Taurog, A. 1976. The mechanism of action of the thioureylene antithyroid drugs. Endocrinology 98: 1031-1046

26. Todd, G.C. 1986. Induction and reversibility of thyroid proliferative changes in rats given an antithyroid compound. Vet. Pathol. 23: 110-117.

27. Van den Berg, K.J., Zurcher, C. and Brouwer, A. 1988. Effects of 3,4,3',4'-tetrachloro-biphenyl on thyroid function and histology in marmoset monkeys. Toxicol. Lett. 4: 77-86.

28. Zbinden, G. 1987. Assessment of hyperplastic and neoplastic lesions of the thyroid gland. Trends Pharmacol. Sci. 8: 511514. 